\title{
Egg Traits and Productive Performance of Isa-Brown Laying Hens Fed Garlic Supplemented Diets
}

\author{
*Fajemilehin Samuel Oladipo Kolawole and Alamuoye Oluwatoyin Folake \\ Department of Animal Science, Faculty of Agricultural Sciences, Ekiti State University \\ Ado-Ekiti, Nigeria \\ ${ }^{*}$ Corresponding author's email: dipofajemilehin [AT] yahoo.com
}

\begin{abstract}
The effect of garlic supplementation on egg traits and productive performance of laying chickens have been widely studied but little information is available on the basis of strains while the issue of level of inclusion is an ongoing debate. This study investigated the effect of garlic supplementation on the productive performance and egg traits of Isa-brown, a specific strain of laying hen. Forty eight Isa Brown layers were randomly selected and allocated to four dietary treatments; each treatment had twelve layers consisting of three in a cage compartment and in four replicates. The treatments consisted a control, $0.5,1$ and $2 \%$ garlic powder supplemented diets and fed to the layers for twelve weeks. Data were collected on growth parameters, egg traits and cholesterol contents. The dietary treatments significantly $(p<0.05)$ reduced the body weight, feed intake, egg weight and hen-day egg production to the least values at the $2 \%$ level of garlic powder inclusion but the feed efficiency was not affected. Garlic supplementation significantly $(p<0.05)$ increased the albumen index, shell index, shell weight, Haugh unit and yolk cholesterol. The 1\% garlic inclusion level gave the highest albumen index and Haugh unit while the highest shell index at $2 \%$ garlic supplementation was due to significant $(p<0.05)$ reduction in shell weight. Garlic significantly $(p<0.05)$ decreased the egg yolk cholesterol but did not affect the yolk index and the yolk weight. Garlic supplementation in Isa Brown layers' diet should not exceed $1 \%$ inclusion in order to avoid reduced productive performance and egg quality.
\end{abstract}

Keywords--- Isa-Brown laying hens, garlic supplementation, productive performance, egg traits

\section{INTRODUCTION}

Hen egg production totaled 636,000 metric tons valued at $\$ 527.49$ million in Nigeria, ranking her $19^{\text {th }}$ in the world and the top producer in Africa in 2011 [1]. The common breeds of laying chickens in Nigeria include the Bovans Black, Dekalb-Amberlink and the Isa Brown produced by Institut de Sélection Animale (ISA) [2]. Isa Brown is the most popular and most widely used in egg-preneur enterprise because of its low maintenance cost, adaptability to varying climatic conditions and prolificacy that can reach 300 eggs per hen in the first year of laying [3]. Hens bred to lay eggs in such a large quantities often suffer from major disease challenges, some of which are zoonotic [4]. In the past, the approach to meeting the challenges involved the use of antibiotics which are currently facing serious criticism due to drug resistance by bacteria and the presence of drug residues in eggs. Researches into alternative approaches as panacea have led to the interest in natural herbs such as garlic (Allium sativum) for inclusion in the diets. Garlic provides flavour and possesses value-added health characteristics and health-promoting photochemicals. It is a good source of dietary fibre, vitamin $\mathrm{C}$ and folic acid. It contains calcium, iron, low level of sodium with high protein quality and no fat which could be used to alleviate problems associated with high body and egg cholesterol [5].

The effects of garlic supplemented diets on the performance characteristics of broilers had been widely studied but with different outcomes. Some of the results showed improved performance in body weight gain and feed conversion ratio [6-9] and reduced hepatic cholesterol concentration [10-11] while in others there was no influence on the feed intake and feed conversion ratio at low levels of inclusion but a depression at high levels of inclusion [12-13] due to increased feed refusal by hens with subsequent reduction in production [14].

Garlic powder inclusion in the diets of 21 week-old SHSY-type brown layers did not significantly affect body weight, egg production, feed consumption, feed efficiency, egg shell index, egg breaking strength, egg shell thickness, egg albumen index, egg yolk index, egg Haugh unit, egg yolk weight and serum protein concentration but increased egg weight and reduced the egg cholesterol concentration [15]. In 50-week old Hy-line white layers, dietary garlic powder supplementation at $0.5,1$, and $2 \%$ did not affect feed consumption, feed efficiency, egg yolk index, egg yolk weight , egg albumen index, egg shell index, egg Haugh unit and plasma high-density lipoprotein (HDL) cholesterol concentrations but increased egg production while yolk cholesterol concentration, Plasma low-density lipoprotein (LDL) cholesterol concentrations decreased [16]. The supplementation of layers, diets with onion and garlic extracts had a positive effect on 
the production rate in the initial and peak egg-laying period, and significantly determined the aroma and taste of boiled eggs [17-19].

The consensus has not been reached on the level of inclusion in all these reports and may not be forthcoming as the studies were conducted in different environments in which genotype, environment and genotype $\mathrm{x}$ environment interactions would affect the results. Therefore, the objective of this study was to investigate the extent at which garlic powder supplementation in the diets will influence the laying performances and egg traits of Isa-Brown laying hens in South-western Nigeria.

\section{MATERIALS AND METHODS}

The study was carried out at the Poultry Unit of the Teaching and Research Farm, Ekiti State University, Ado-Ekiti, Nigeria between $15^{\text {th }}$ of March to $15^{\text {th }}$ of June, 2017. Forty eight Isa-Brown layers in 24 weeks of production kept in a 45 x 40 x $38 \mathrm{~cm}$ battery cage system equipped with drinkers and feeders in an open sided house with dwarf wall were selected for the study. Four compartments in a cage were randomly allotted to each of the 4 dietary treatments with each compartment containing 3 birds as experimental units in four replicates. The garlic cloves were peeled, washed, sliced to pieces of 3 to $4 \mathrm{~mm}$, sun dried and ground to a mesh size of $160 \mu \mathrm{m}$ before incorporation into the experimental diets formulated to meet the minimum nutrient requirements for layers [20] as shown in Table 1.

The proximate compositions of the experimental feeds were determined using standard analytical procedures [21]. The birds were served weighed quantities of feed at $8 \mathrm{a} . \mathrm{m}$. daily. The left over feeds were weighed before serving fresh feed. Fresh, cool and clean water was supplied liberally and uniformly throughout the day. Data were collected on the following:

\subsection{Performance Parameters}

The parameters evaluated are: weight gain; feed intake, egg weight, feed efficiency and hen-day egg production.

i. Weight gain calculated as the difference between the final and initial body weights of the hens;

ii. Feed intake recorded weekly;

iii. Feed efficiency calculated during the 12 weeks of the experimental period in $\mathrm{kg}_{\mathrm{g}}$ of feed $\mathrm{kg}^{-1}$ of egg and

iv. Egg production recorded daily and the percentage hen-day production computed as:

Total number of eggs $\mathrm{x} 100$

Total number of days $\mathrm{x}$ Total number of hens

\subsection{Egg Trait Measurements}

At the end of the experiment, 8 eggs were collected from each treatment to determine the weights of the egg, shell, yolk and albumen. The egg albumen index, egg yolk index, egg shape index and egg Haugh unit were determined as follows:

Albumen index $=\frac{\text { Average height of the thick albumen }}{\text { Albumen width }}$
Egg Yolk index $=\frac{\text { Average height of the yolk }}{\text { Yolk width }}$
Egg shape index $=\frac{\text { Average width of the egg }}{\text { Average length }}$
Haugh Unit $=100 \mathrm{log}$ (Height of thick albumen $+7.57-1.7$ Egg Weight $^{0.37}$

\subsection{Cholesterol determination}

At the end of the experiment, 4 eggs were collected from each replicate per treatment, hard-boiled to separate the yolk and cooked yolk weights recorded. The cooked yolk was extracted and subsequently analysed for the cholesterol concentration per yolk in an automatic analyzer (Hitachi 747, Hitachi Co., Tokyo, Japan) by direct enzymatic kits.

\subsection{Statistical Analysis}

The data obtained were subjected to One Way ANOVA using SPSS for Windows, version 11.5 and Duncan's multiple range test [22] was used as means separator where statistical differences of means were obtained. 


\section{RESULTS}

\subsection{Performance characteristics of laying hens fed garlic supplemented diets}

Table 2 shows the effects of garlic powder on the performance characteristics of Isa-Brown laying hens. The initial body weight (BDWs) of the birds were similar $(p>0.05)$ but the treatments had caused significant $(p<0.05)$ weight loss [body weight at the end (BDEe)] at the end of the experiment. Also, the feed intake (FI), egg weight (EW) and hen-day egg production $(\mathrm{HdEP})$ were significantly affected $(\mathrm{p}<0.05)$ by garlic supplementation with the lowest BDW $\mathrm{e}$, FI, EW and HdEP were recorded at $2 \%$ while the control, 0.5 and $1 \%$ garlic supplemented diets were similar $(\mathrm{p}>0.05)$. However, the feed efficiency (FE) was not affected $(\mathrm{p}>0.05)$ by all levels of garlic powder inclusion in the diets.

\subsection{Effects of garlic powder on the egg traits of Isa-brown laying hens}

Table 3 shows that garlic supplementation had significant effects $(\mathrm{p}<0.05)$ on the albumen index $(\mathrm{AI})$, shell index (SI), shell weight (SW), Haugh unit (HU) and yolk cholesterol (YC) of Isa Brown laying hens. The albumen index was highest $(\mathrm{p}<0.05)$ at $1 \%$ garlic inclusion level with while the highest shell index (SI) was obtained at $2 \%$ garlic inclusion level. Garlic inclusion reduced $(p<0.05)$ the shell weight with the highest value of $5.50 \pm 0.02 \mathrm{~g}$ in the control diet. The Haugh unit was highest $(\mathrm{p}<0.05)$ at 1 and $2 \%$ garlic inclusion and least at $0.5 \%$ inclusion level. The egg yolk cholesterol (YC) decreased $(\mathrm{p}<0.05)$ from $19.27 \pm 0.5 \mathrm{mg} / \mathrm{g}$ in control to $11.20 \pm 0.07 \mathrm{mg} / \mathrm{g}$ at $2 \%$ garlic inclusion level. However, garlic supplementation had no effect $(\mathrm{p}>0.05)$ on the yolk index and the yolk weight.

\section{DISCUSSION}

In this study, garlic inclusion caused progressive decline in body weight, feed intake, egg weight and hen-day egg production in Isa Brown laying hens but did not affect the feed efficiency. The reduced body weight of the hens at the end of the treatment was probably due to mobilization of nutrients in feed and body metabolites stored for laying rather than body weight gain. This is expected as egg laying is an energy sapping activity. The final weight of the hens and hen day production increased up to $1 \%$ of garlic supplementation but were depressed at $2 \%$ garlic inclusion. Earlier reports indicate significant weight gain and increased egg production without effects on feed intake and efficiency when garlic powder was included at $1 \%$ in hen's diet $[19,23]$. However, the result is not in agreement with reports that body weight gain, egg weight and egg production were not affected when garlic was included in the diets of laying hens [14, 15, 18, 24]. The implication is that garlic inclusion up to $1 \%$ enhances growth rate and egg traits but above the depressing effect occurs probably because of the anti-nutritional factors present in garlic.

Table 1: Composition of experimental diets (\%) for Isa-Brown laying hens

\begin{tabular}{|c|c|c|c|c|}
\hline Ingredients & $\begin{array}{l}\mathrm{T}_{1} \\
\text { Control diet }\end{array}$ & $\begin{array}{l}\mathrm{T}_{2} \quad(0.5 \% \text { garlic } \\
\text { addition })\end{array}$ & $\begin{array}{l}\mathrm{T}_{3}(1 \% \text { garlic } \\
\text { addition) }\end{array}$ & $\begin{array}{l}\mathrm{T}_{4}(2 \% \text { garlic } \\
\text { addition })\end{array}$ \\
\hline Maize & 49.00 & 48.50 & 48.00 & 47.00 \\
\hline Garlic powder & 0.00 & 0.50 & 1.00 & 2.00 \\
\hline Groundnut cake & 8.00 & 8.00 & 8.00 & 8.00 \\
\hline Soya bean & 12.00 & 12.00 & 12.00 & 12.00 \\
\hline Wheat offal & 18.00 & 18.00 & 18.00 & 18.00 \\
\hline Fishmeal (72\%) & 2.00 & 2.00 & 2.00 & 2.00 \\
\hline Bone meal & 2.50 & 2.50 & 2.50 & 2.50 \\
\hline Oyster shell & 7.00 & 7.00 & 7.00 & 7.00 \\
\hline $\mathrm{NaCl}$ & 0.25 & 0.25 & 0.25 & 0.25 \\
\hline Methionine & 0.50 & 0.50 & 0.50 & 0.50 \\
\hline Lysine & 0.25 & 0.25 & 0.25 & 0.25 \\
\hline Premix & 0.50 & 0.50 & 0.50 & 0.50 \\
\hline Total & 100.00 & 100.00 & 100.00 & 100.00 \\
\hline \multicolumn{5}{|c|}{ Calculated composition } \\
\hline C.P $(\%)$ & 17.10 & 17.08 & 17.07 & 17.07 \\
\hline C.F $(\%)$ & 4.20 & 4.22 & 4.23 & 4.22 \\
\hline ME (MEkcal/kg & 2757.37 & 2755.38 & 2756.36 & 2753.35 \\
\hline
\end{tabular}


Feed efficiency was not affected by garlic inclusion in this study which agrees with the findings on laying hens [25]; in native Desi laying hens [26] and in Babcock B-300 laying strains [27] fed garlic supplemented diets. The difference in feed intake obtained however contradicts the reports indicating a direct relationship between feed intake and garlic inclusion in the diets of laying hens [19,25-27] while the decrease at $2 \%$ garlic inclusion level was probably associated with the specific odour of garlic [25, 28]. The different results obtained when diets of laying hens were supplemented with garlic powder probably occurs because properly fed healthy birds housed under clean environment and moderate stocking density may not respond to a performance- promoting supplement [29].

The albumen index, shell index and Haugh unit obtained in this study agree with earlier worker [25] but disagree with the findings of another researcher who fed 5 and $10 \mathrm{~g}$ garlic $\mathrm{kg}^{-1}$ of feed to laying hens [15]. The Haugh unit, a trait that determines the quality of the egg was highest at $1 \%$ garlic inclusion indicating that the quality of the eggs was best at this level of inclusion which is in agreement with the findings of earlier researchers [18]. The reduction in eggshell weight with increased garlic powder supplementation disagrees with the findings that garlic powder supplementation had a positive effect on the weight of the eggshell [30].

The yolk index and the yolk weight agree with the reports of earlier researchers [15, 25] but disagrees with the findings of others who obtained a reduction in yolk weight at inclusion levels of 5, 10 and $15 \mathrm{~g}^{\text {of }}$ garlic $\mathrm{kg}^{-1}$ of feed [31]. The reason for these differences might be due to variations in the levels of garlic powder, differences in strains and/or variation in the environmental conditions.

The mean egg yolk cholesterol concentration was reduced by garlic supplementation in this study. Compared to the control diet, there was a 36.64, 38.30 and $36.69 \%$ reduction in egg cholesterol at $0.5,1$ and $2 \%$ garlic supplementations respectively. The decrease in the yolk cholesterol obtained agrees with the reports of previous researchers who obtained significant reduction in egg yolk cholesterol [19, 24].

\section{CONCLUSION}

Garlic supplementation in Isa Brown layers' diet should not exceed $1 \%$ inclusion in order to avoid reduced productive performance and egg quality.

Table 2: Effects of garlic powder on the performance of Isa-Brown laying hens

\begin{tabular}{l|l|c|c|c}
\hline Parameters & $\begin{array}{c}\mathrm{T}_{1} \\
\text { Control diet }\end{array}$ & $\begin{array}{c}\mathrm{T}_{2} \\
0.5 \% \text { garlic addition }\end{array}$ & $\begin{array}{c}\mathrm{T}_{3} \\
1 \% \text { garlic addition }\end{array}$ & $\begin{array}{c}\mathrm{T}_{4} \\
2 \% \text { garlic addition }\end{array}$ \\
\hline BDWs (g) & $1,623.0 \pm 2.31$ & $1,657.2 \pm 2.09$ & $1,625.0 \pm 1.98$ & $1,641.0 \pm 2.03$ \\
BDWe (g) & $1,599.1 \pm 3.42^{\mathrm{a}}$ & $1,640.7 \pm 2.97^{\mathrm{a}}$ & $1,602.4 \pm 2.77^{\mathrm{a}}$ & $1,403.9 \pm 3.30^{\mathrm{b}}$ \\
FI (g day ${ }^{-1}$ bird $\left.^{-1}\right)$ & $114.12 \pm 0.14^{\mathrm{a}}$ & $115.48 \pm 0.13^{\mathrm{a}}$ & $115.81 \pm 0.15^{\mathrm{a}}$ & $112.98 \pm 0.13^{\mathrm{b}}$ \\
EW (g) & $62.71 \pm 0.04^{\mathrm{a}}$ & $62.83 \pm 0.03^{\mathrm{a}}$ & $62.50 \pm 0.05^{\mathrm{a}}$ & $61.18 \pm 0.04^{\mathrm{b}}$ \\
FE (kg feed kg-1 eggs) & $2.06 \pm 0.01$ & $2.05 \pm 0.03$ & $2.07 \pm 0.02$ & $2.13 \pm 0.042$ \\
HdEP (\%) & $81.43 \pm 0.03^{\mathrm{ab}}$ & $82.63 \pm 0.02^{\mathrm{a}}$ & $83.04 \pm 0.04^{\mathrm{a}}$ & $80.57 \pm 0.05^{\mathrm{b}}$ \\
\hline
\end{tabular}

$a b$ : Means with a different superscript within a column are significantly different

$=$ Feed
efficiency $\mathrm{HdEP}=$ Hen-day egg production 
Table 3: Effects of garlic powder on the egg traits of Isa-Brown laying hens

\begin{tabular}{|c|c|c|c|c|}
\hline \multicolumn{5}{|c|}{ Garlic supplementation (\%) } \\
\hline Parameters & $\begin{array}{l}\mathrm{T}_{1} \\
\text { Control diet }\end{array}$ & $\begin{array}{c}\mathrm{T}_{2}(0.5 \% \\
\text { garlic addition })\end{array}$ & $\begin{array}{c}\mathrm{T}_{3}(1 \% \\
\text { garlic addition })\end{array}$ & $\begin{array}{l}\mathrm{T}_{4}(2 \% \\
\text { garlic addition) }\end{array}$ \\
\hline Albumen index & $6.85 \pm 0.02^{\mathrm{b}}$ & $6.78 \pm 0.03^{b}$ & $7.27 \pm 0.04^{\mathrm{a}}$ & $7.12 \pm 0.02^{\mathrm{ab}}$ \\
\hline Yolk index & $37.41 \pm 0.07$ & $37.22 \pm 0.06$ & $37.28 \pm 0.04$ & $37.75 \pm 0.05$ \\
\hline Shape index & $72.31 \pm 0.06^{\mathrm{ab}}$ & $72.43 \pm 0.05^{\mathrm{ab}}$ & $71.77 \pm 0.06^{\mathrm{b}}$ & $72.92 \pm 0.08^{\mathrm{a}}$ \\
\hline Shell weight $(g)$ & $5.50 \pm 0.02^{\mathrm{a}}$ & $5.26 \pm 0.01^{\mathrm{b}}$ & $5.36 \pm 0.03^{\mathrm{ab}}$ & $5.30 \pm 0.01^{b}$ \\
\hline Haugh unit & $74.68 \pm 0.08^{b c}$ & $73.95 \pm 0.09^{c}$ & $76.81 \pm 0.07^{\mathrm{a}}$ & $76.12 \pm 0.07^{\mathrm{ab}}$ \\
\hline Yolk weight $(\mathrm{g})$ & $16.75 \pm 0.05$ & $17.08 \pm 0.04$ & $16.81 \pm 0.03$ & $16.48 \pm 0.95$ \\
\hline Yolk cholesterol $(\mathrm{mg} / \mathrm{g})$ & $19.27 \pm 0.5^{\mathrm{a}}$ & $12.21 \pm 0.07^{\mathrm{b}}$ & $11.89 \pm 0.05^{\mathrm{b}}$ & $11.20 \pm 0.07^{\mathrm{b}}$ \\
\hline
\end{tabular}

$a b c:$ Means with a different superscript within a column are significantly different $(p<0.05)$

\section{REFERENCES}

[1]. USDA, United State Department of Agriculture, "International egg and poultry review". http://www.thepoultrysite. com/reports /?id=1596, vol. 16 , no. 0, pp. $1-3,2103$.

[2]. PM, "The Benefits of the ISA Brown Layers for Nigerian Poultry Producers" Poultry Manual at https://poultrymanual.com/2016/05/07/benefits-isa-brown-layers-nig erian-poultry-producers/, 2015

[3]. Anonymous, http://www.ces.ncsu.edu/depts/poulsci/tech manuals/layer reports/38 single cycle report, 2014.

[4] Maruta K., "Probiotics", World Poultry. No. 23, pp. 14. 2007.

[5]. Lorena R., "Eating Onions and Garlic for Their Antioxidants and Other Health Benefits yahoo contributor network", 2011.

[6]. Onu P.N., "Evaluation of two herbal spices as feed additives for finisher broilers". Biotechnology in Animal Husbandry, vol. 26, no. 5-6, pp 383 - 390, 2010

[7]. Kumar S., K.C.Sharadamma, P.M. Radhakrishna, "Effects of garlic active based growth promoter on growth performance and specific pathogenic intestinal microbial counts of broiler chicks". Poultry Science, no. 9, pp. 244- 246, 2010.

[8]. Demir E., Sarica S., Ozcan M. A., Suicmez M., "The use of natural feed additives as an alternative for an antioxidative growth promoter in broiler diet”. Brit. Poult. Sci. no. 44 (Suppl.), pp. S44, 2003.

[9]. Lewis M.R., Rose S.P., Mackenzie A.M., Tucker L.A., "Effects of dietary inclusion of plant extracts on the growth performance of male broiler chickens", British Poultry Science. 44 (S1): 43-44, 2003.

[10]. Cullen S.P., Monahan F.J., Callan J.J., O'Doherty J.V., "The effect of dietary garlic and rosemary on growerfinisher pig performance and sensory characteristics of pork” Irish. J. Agric. Food Res. no. 44, pp. 57-67, 2005.

[11]. Fayed R.H., Razek A.H.A., Jehan, M.O, "Effect of dietary garlic supplementation on performance, carcass traits, and meat quality in broiler chickens", In Animal hygiene and sustainable livestock production Proceedings of the XVth International Congress of the International Society for Animal Hygiene, Vienna, Austria, no. 1, pp. 471- 474, 2011.

[12]. Javandel F., B. Navidshad J. Seifdavati G. H. Pourrahimi, S. Baniyaghoub, (2008). "The favorite dosage of garlic meal as a feed additive in broiler chickens ratios", Pakistan Journal of Biological Science, vol. 11, no. 13, pp $1746-1749,2008$. 
[13]. Ashayerizadeh A., N. Dabiri, O. Ashayerizadeh, K. H. Mirzadeh, H. Roshanfekr, M. Mamore, "Effect of dietary antibiotic, probiotic and prebioticas growth promoters on growth performance, carcass characteristics and hematological indices of broiler chickens”, Pakis. J. Biol. Sci. no. 12, pp. 52-57, 2009.

[14]. Olobatoke R. Y., Mulugeta S. D., "Effect of dietary garlic powder on layer performance, fecal bacterial load, and egg quality”, Poultry Science, no. 90, pp. 665-670, 2011.

[15]. Yalcin S., Onbasilar E.E., Reisli Z., Yalcin S., "Effect of garlic powder on the performance, egg traits and blood parameters of laying hens". Journal. Sci. Food Agric. Vol. 86, no. 9, pp. 1336-1339, 2006.

[16]. Canogullari S., Karaman M., Erdogan Z., Baylan M., Kucukgul A., Duzguner V. and Ozugur A. K. (2009). Effect of Garlic Powder on Egg Yolk and Serum Cholesterol and Performance of Laying Hens. Bull Vet Inst Pulawy, no. 53, pp. 515-519, 2009.

[17]. Krzysztof D., Riedel J., Gozdowski, D. Niemiec J., Siennicka A. and Rog D, "Productive performance and egg quality of laying hens fed diets supplemented with Research, vol. 26, no. 3, 2017. garlic and onion extracts", The Journal of Applied Poultry

[18]. Lim K.S., You S.J., An B.K., Kang C.W., "Effects of dietary garlic powder and copper on cholesterol content and quality characteristics of chicken eggs". Asian-Australian Journal of Animal Science, no. 19, pp. 582-586, 2006.

[19]. Khan S.H., Sardar R., Anjum, M.A., "Effects of dietary garlic on performance and serum and egg yolk cholesterol concentration in laying hens". Asian-Australian Journal of Animal Science, no. 1, pp. 22-27, 2007.

[20]. NRC., National Research Council. Nutrient "Requirements of Poultry. 9th rev. ed. Natl” (Acad. Press, Washington, DC), 1994.

[21]. AOAC, Official methods of analysis of AOAC International, 17 $7^{\text {th }}$ edition; $\quad$ (Gaithersburg, MD, USA Association of Analytical Chemistry), 2000.

[22]. Duncan D. B., "Multiple range and multiple F test", Biometrics, no. 1, pp. 1 - 42,

1955.

[23]. Marshall, A. A., and E. E. Kokoete, "Egg yolk cholesterol lowering effects of garlic and tea" Journal of Biological. Science, no. 8, pp.456-460, 2008.

[24]. Chowdhury S.R., Chowdhury S.D., Smith T.K., "Effects of dietary garlic on cholesterol metabolism in laying hens", Poultry Science, no. 81: 1856-1862, 2006.

[25]. Sibel C., Mesut K., Zeynep E., Mikail B., Altug K., Vesile, D. and Alikemali O., "Effect of garlic powder on egg yolk and serum Cholesterol and performance of laying hens", Bull vet inst pulawy, no. 53, pp. 515-519, 2009.

[26]. Khan S.H., Hasan S., Sardar R., Anjum M.A., "Effects of dietary garlic powder on cholesterol concentration in Native Desi laying hens", American Journal of Food Technology, no. 3, pp. 207- 213, 2008.

[27]. Reddy R.V., Lightsey S.F. and Maurice D.V., "Effect of feeding garlic oil on performance and egg yolk cholesterol concentration”, Poultry Science, no. 70, pp. 2006- 2009, 1991.

[28]. Qureshi A.A., Din Z.Z., Abuirmeileh N., Burger W.C., Ahmad Y. and Elson C.E., "Suppression of avian hepatic lipid metabolism by solvent extracts of garlic: Impact on serum lipids", Journal of Nutrition, no. 113 , pp 1746-1755, 1983.

[29]. Botsoglou N., P. Florou-Paneri, E. Botsoglou, V. Dotas, I. Giannenas, A. Koidis and P. Mitrakos, "The effect of feeding rosemary, oregano, saffron and $\alpha$ - tocopheryl acetate on hen performance and oxidative stability of eggs. South African Journal of Animal Science, no. 35, pp.143-151, 2005.

[30]. Azeke M.A., Ekpo K.E., "Egg yolk cholesterol lowering effects of garlic and tea", Journal of Biologial. Science, no. 8, pp. 456-460, 2008.

[31]. Mottaghitalab M., Taraz Z., "Garlic powder as blood serum and egg yolk cholesterol lowering agent", Journal of Poultry Science, no. 41, pp. 50-57, 2004. 